\title{
Penentuan Barcode DNA berdasarkan Gen matK dan Analisis In-silico MatK Rumput Macan (Lantana camara L.)
}

\author{
Billy L. Mokoagowa* ${ }^{*}$, Feti Fatimaha, Maureen Kumaunanga
}

aJurusan Kimia, FMIPA, Unsrat, Manado

\section{KATA KUNCI}

tumbuhan rumput macan

Lantana camara L.

matk

Barcode DNA

analisis in-silico

\begin{tabular}{l}
$\overline{\text { AVAILABLE ONLINE }}$ \\
\hline 10 Februari 2015 \\
\hline
\end{tabular}

\section{K E Y W O R D S}

Rumput macan plant

Lantana camara L.

matK

Barcode DNA

In-silico analysis

\begin{abstract}
A B S TR A K
DNA barcoding merupakan metode identifikasi spesies menggunakan potongan DNA pendek yang disebut barcode DNA. Gen matK merupakan gen standar untuk penentuan barcode DNA tanaman. Penelitian ini bertujuan untuk menentukan barcode DNA tumbuhan rumput macan ( $L$. camara L.) berdasarkan gen matK, serta melakukan analisis in-silico terhadap produk gen matK tumbuhan rumput macan (L. camara L.) dengan kerabat terdekatnya. Gen matK L. camara L. telah berhasil diamplifikasi dengan Polymerase Chain Reaction (PCR) menggunakan primer forward matK-1RKIM-f dan primer reverse matK-3FKIM-r. Analisis terhadap sekuens matK L. camara L. menunjukkan bahwa barcode DNA tumbuhan rumput macan (L. camara L.) terdiri dari 843 nukleotida. Selanjutnya, hasil analisis in-silico menunjukkan bahwa matK Lantana camara L. bersifat basa, stabil, dan dapat berinteraksi baik dengan air.

A B S T R A C T

DNA barcoding is a method of species identification using short pieces of DNA called DNA barcode. matK is a standard gene to determine DNA barcode of a plant. The aim of this research was to determine the DNA barcode of Rumput Macan plant (Lantana camara L.) based on matK gene, as well as in-silico analysis of the product matK gene Rumput Macan ( $L$ camara L.) with its closest relatives. L. camara L. matK gene was successfully amplified by Polymerase Chain Reaction (PCR) using forward primer MATK-1RKIM-f and reverse primer MATK-3FKIM-r. Analysis of the matK sequence of $L$. camara $L$. showed that the barcode DNA of rumput macan plant ( $L$. camara L.) consisting of 843 nucleotides. Furthermore, the result of in-silico analysis showed that the matK of $L$ camara $L$. is alkaline, stable, and able to interact well with water.
\end{abstract}

\section{Pendahuluan \\ Daun Rumput Macan mengandung saponin, flavanoid dan minyak atsiri. Senyawa flavonoid telah dikenal memiliki efek antiinflamasi dan juga memiliki efek antipiretik yang bekerja sebagai inhibitor cyclooxygenase (COX) yang berfungsi memicu pembentukan prostaglandin. Prostaglandin berperan dalam proses inflamasi dan peningkatan suhu tubuh. Apabila prostaglandin tidak dihambat akan terjadi peningkatan suhu tubuh yang akan mengakibatkan demam (Hidayati, 2005).}

Metode identifikasi spesies makhluk hidup telah berkembang dari identifikasi morfologi sampai pada identifikasi molekuler berdasarkan potongan DNA pendek yang disebut "barcode DNA" (Hebert et al. 2003). Barcode DNA memiliki fungsi-fungsi aplikatif misalnya untuk survei ekologi (Dick dan Kress 2009), identifikasi takson-takson kriptik (Lahaye et al. 2008), dan konfirmasi sampel-sampel tanaman obat (Xue dan Li 2011).

The Consortium for the Barcode of Life (CBOL Plant Working Group, 2009) merekomendasikan penggunaan dua gen plastida yaitu ribulosa-1,5bifosfat karboksilase $(r b c L)$ dan gen maturase $\mathrm{K}$ (matK) sebagai barcode standar untuk DNA tumbuhan (Hollingsworth et al. 2009). 
Sampai saat ini, penelitian tentang barcode DNA dan karakteristik matK rumput macan asal Indonesia belum pernah dipublikasikan. Untuk itu, perlu dilakukan penelitian mengenai barcode DNA dan karakterisasi produk gen matk tumbuhan rumput macan (L. camara L.).

\section{Metode}

\subsection{Alat}

Alat yang digunakan dalam penelitian ini adalah alatalat gelas, hot plate, tabung Eppendorf 1,5 mL, tabung PCR $50 \mu \mathrm{L}$, mikropipet, inkubator, microcentrifuge, alat PCR (Biometra T-personal, Jerman), elektroforesis, UV-transiluminator, dan lemari pembeku.

\subsection{Bahan}

Bahan yang digunakan dalam penelitian ini adalah daun Rumput Macan yang diperoleh dari desa Basaan Kabupaten Minahasa Tenggara. Kit untuk isolasi DNA tanaman menggunakan InnuPREP Plant DNA kit (Analytik Jena), primer forward matK-1RKIM-f dan primer reverse matK-3FKIM-r (Integrated DNA Technology (IDT), Singapura), master mix untuk PCR (GoTaq ${ }^{\circledR}$ Master Mix, Promega), agarosa (Merck), akuades, etidium bromida (Merck) dan bufer Trisborat-EDTA (TBE, Promega).

\subsection{Prosedur Penelitian}

\subsubsection{Isolasi DNA total Tumbuhan Ruumpu Macan}

Isolasi DNA total dilakukan berdasarkan manual prosedur dari InnuPrep Plant DNA Kit yang dimodifikasi. Sampel rumput macan dalam tabung Eppendorf ditambahkan Lysis Solution (LS) sebanyak $300 \mu \mathrm{L}$ dan proteinase $\mathrm{K}$ sebanyak $25 \mu \mathrm{L}$ dengan menggunakan mikropipet dan diinversikan beberapa kali agar homogen. Diinkubasi selama 45 menit pada suhu $55^{\circ} \mathrm{C}$ menggunakan termoblok dan diinversikan kembali setiap 10 menit. Sampel dimasukkan dalam prefilter untuk difiltrasi. Kemudian disentrifugasi $12.000 \mathrm{rpm}$ selama 1 menit Filtrat diambil dan ditambahkan binding solution SBS $200 \mu \mathrm{L}$, dicampurkan dengan menggunakan pipet. Filtrat dituang dalam spin filter untuk difiltrasi kembali. Disentrifugasi 12.000 rpm selama 1 menit kemudian filtrat dibuang dan dimasukkan kembali Spin Filter kedalam Receiver Tube. Ditambahan Washing Solution HS $500 \mu \mathrm{L}$ dan disentrifugasi $12.000 \mathrm{rpm}$ selam 1 menit. Filtrat dibuang dan Spin Filter dimasukkan kembali ke Receiver Tube. Ditambahkan Washing Solution MS $750 \mu \mathrm{L}$ dan di sentrifugasi 12.000 rpm selama 1 menit. Filtrat dibuang dan Spin Filter dimasukkan kembali ke Receiver Tube. Sentrifugasi $12.000 \mathrm{rpm}$ (atau full speed) selama 1 menit. Spin Filter dipindahkan ke dalam Elusion Tube (tabung Eppendorf) Ditambahkan Elussion Buffer 100 $\mu \mathrm{L}$ dan di diamkan pada suhu ruang selama 1 menit kemudian disentrifugasi $10.000 \mathrm{rpm}$ selama 1 menit. DNA disimpan dalam lemari pendingin pada suhu $10^{\circ} \mathrm{C}$.

\subsubsection{Polymerase Chain Reaction (PCR) dan Penentuan Urutan Nukleotida matK}

Reaksi PCR dilakukan dalam volume total $40 \mu \mathrm{L}$ dalam tabung PCR $50 \mu \mathrm{L}$. Di dalam setiap reaksi memiliki $2 \mu \mathrm{L}$ DNA sampel(DNA templat), $20 \mu \mathrm{L}$ Go Tag Master Mix 2x, 1,5 $\mu \mathrm{L}$ Primer Forward (5'ACCCAGTCCATCTGGAAATCTTGGTTC-3'), 1,5 $\mu \mathrm{L}$ Primer Reverse (5'CGTACAGTACTTTTGTGTTTACGAG-3')dan $15 \mu \mathrm{L}$ dd $\mathrm{H}_{2} \mathrm{O}$. Pengaturan suhu mesin PCR yang digunakan, yaitu denaturasi awal templat DNA dilakukan pada suhu $95^{\circ} \mathrm{C}$ selama 2 menit. Selanjutnya siklus amplifikasi dilaksanakan sebanyak 35 kali, yaitu denaturasi dilakukan pada suhu $95^{\circ} \mathrm{C}$ selama 30 detik, penempelan primer dilakukan pada suhu $50^{\circ} \mathrm{C}$ selama 30 detik, dan DNA extension pada suhu $72^{\circ} \mathrm{C}$ selama 50 detik. Tahap pemantapan yaitu final extension dilakukan pada suhu $72^{\circ} \mathrm{C}$ selama 1 menit. Hasil PCR berupa fragmen DNA kemudian dielektroforesis menggunakan gel agarosa $1 \%$ dan divisualisasi dengan uv-transiluminator. Sampel hasil PCR selanjutnyya disekuensing di First Base Laboratories Sdn Bhd, Malaysia.

\subsubsection{Analisis Barcode DNA}

Kromatogram DNA hasil sekuensing disunting menggunakan perangkat lunak Geneious v5.6.4. Bagian awal dan akhir hasil kromatogram DNA tersebut dihapus kira-kira $30 \mathrm{bp}$ (pasang basa) dan untuk pembacaan nukleotida yang keliru diperbaiki berdasarkan tingkat keakuratan yang terbaca (Drummond et al., 2012). Selanjutnya keakuratan amplifikasi gen target yang diuji menggunakan gen matK, diidentifikasi melalui BOLD (Barcode of Life Database) Systems (www.boldsystems.org), yang dapat diakses secara gratis (Ratnasingham and Hebert, 2007).

\subsubsection{Analisis Sekuen matK secara In-silico}

Tahapan analisis in-silico matK dilakukan dengan cara dipilih 7 sekuen protein matK lantana camara L. yang tersedia di National Center of Biotechnology Information (NCBI) (www.ncbi.nlm.nih.gov). Tabel 1 menunjukkan protein yang dipilih dalam analisis insilico. Sekuen protein diunduh dalam format FASTA, dan dilakukan penjajaran terhadap kesepuluh sekuen protein tersebut menggunakan ClustalX (http://www.clustal.org/clustal2/) dan Genedoc (http://www.nrbsc.org/gfx/ genedoc/). Kemudian, dilakukan analisis selanjutnya yang meliputi analisis struktur primer yaitu analisis urutan asam amino dan sifat fisika kimia protein matK tanaman Rumput Macan menggunakan program yang tersedia yaitu ExPasy (http://web.expasy.org/protparam/).

\section{Hasil dan Pembahasan}

\subsection{Hasil Isolasi DNA Total Tumbuhan Rumput Macan}

DNA total Rumput Macan diperoleh setelah melalui proses isolasi DNA yang telah dilakukan. Isolasi DNA total dilakukan untuk mengamplifikasi gen target matk yang terdapat dalam kloroplas tumbuhan rumput macan. 
Produk PCR amplifikasi gen matK menghasilkan fragmen DNA seperti yang ditunjukkan dengan elektroforegram (Gambar 1). Pita DNA yang teramplifikasi yaitu 746 pb untuk primer forward, sedangkan untuk primer reverse yaitu 810.

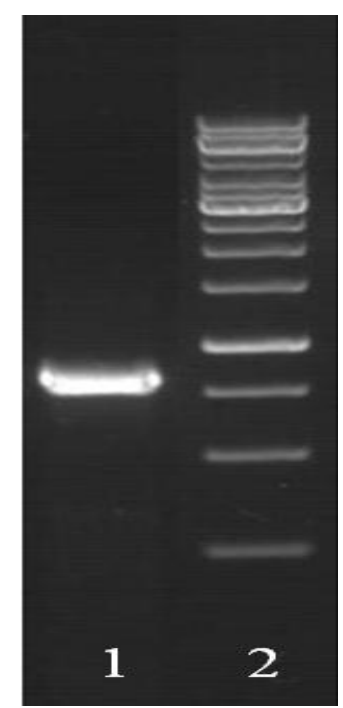

Gambar 1 - Elektroforegram hasil PCR Rumput Macan (Keterangan: 1. Sampel Rumput Macan, 2. Marker DNA ladder $1 \mathrm{pb}$ )

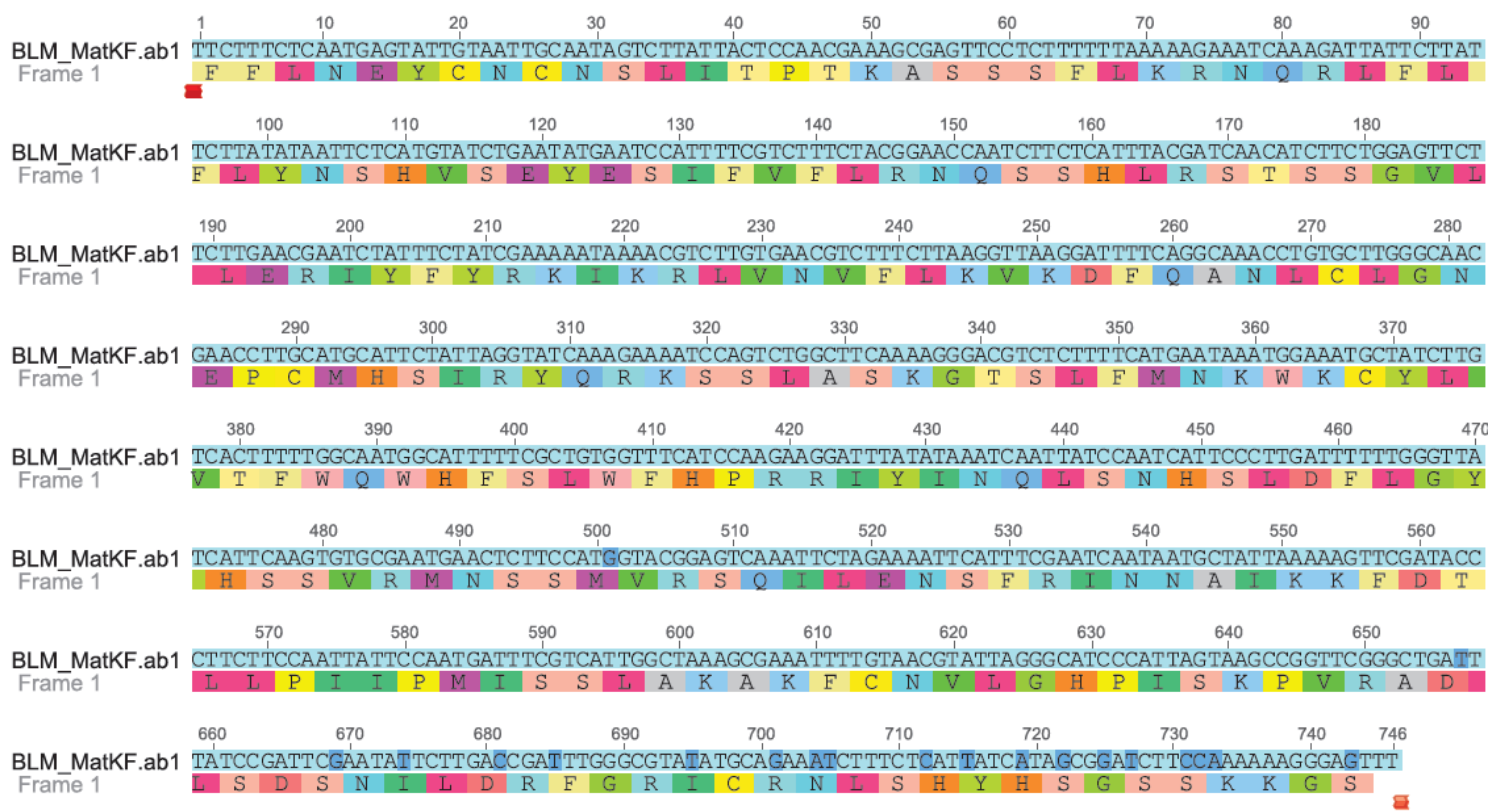

Gambar 2 - Urutan nukleotida dan asam amino hasil sekuensing primer forward matK Rumput Macan. Baris atas menunjukkan urutan nukleotida dan baris bawah menunjukkan urutan asam amino.

Amplifikasi gen matK rumput macan dengan PCR menunjukkan hasil positif seperti yang ditunjukkan Gambar 3. Hasil positif diperlihatkan dengan adanya pita berukuran $\pm 746 \mathrm{pb}$ dan $810 \mathrm{pb}$ dalam Gambar 3 . Hasil positif ini juga menandakan bahwa gen matK rumput macan telah berhasil diampilifikasi menggunakan berurut-turut primer forward dan reverse.

\subsection{Hasil Sekuensing}

Penentuan barcode DNA L. camara L. dilakukan berdasarkan hasil sekuensing produk PCR terhadap gen matk. Proses sekuensing menghasilkan dua sekuens yaitu, hasil sekuens yang menggunakan primer forward (Gambar 2) dan hasil sekuens yang menggunakan primer reverse (Gambar 3) yang disunting dengan menggunakan aplikasi Geneious v5.6.4. 
Pada gambar 4 menunjukkan hasil penggabungan sekuens primer forward dengan sekuens primer reverse menggunakan MUSCLE (Multiple Sequence Comparison by Log-Expectation) yang terintegrasi dalam program Geneious sehingga menghasilkan sekuens yang menjadi barcode DNA rumput macan (L. camara L.). Hasil sekuens kemudian disimpan dalam bentuk FASTA (Fast Alignment) untuk dibandingkan dengan sekuens kerabat terdekat yang diambil dari GenBank (www.ncbi.nlm.nih.gov).

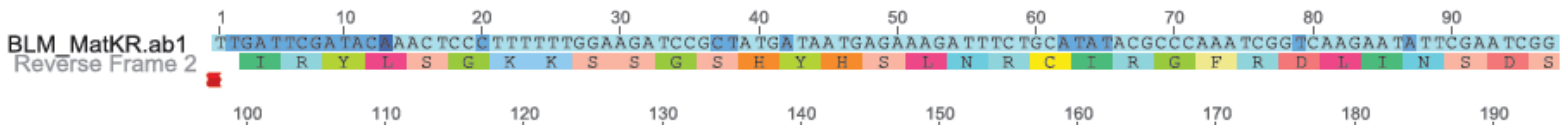

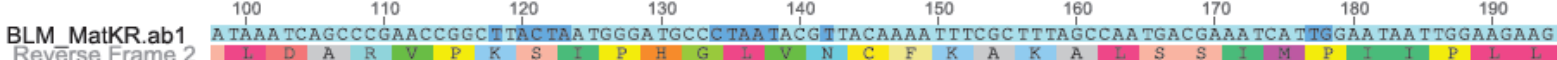
$\begin{array}{llllllll}200 & 210 & 220 & 230 & 240 & 250 & 260 & 270\end{array}$

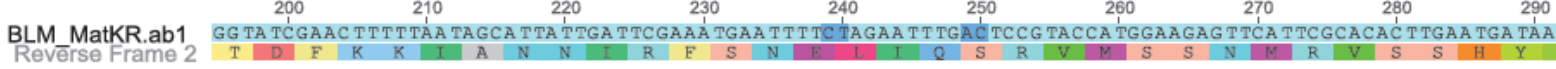
$\begin{array}{lllllll}300 & 310 & 320 & 330 & 340 & 350 & 360\end{array}$ BLM MatKR.ab1 CCCAAAAAA TCAAGGGAATGA TTGGA TAA TTGA TTTATA TAAATCCTTC TTGGA TGAAACCACAGCGAAAAATGCCATTGCCAAAAAG TGACAAGAT

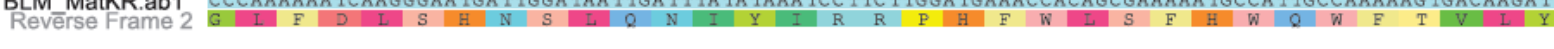

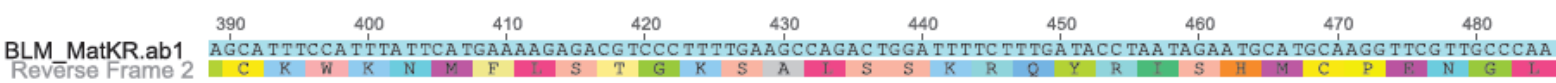

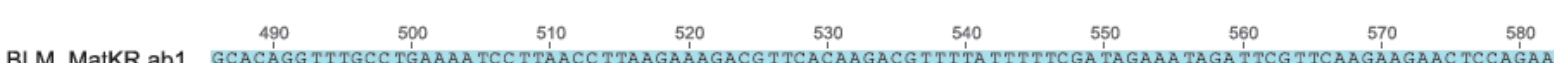

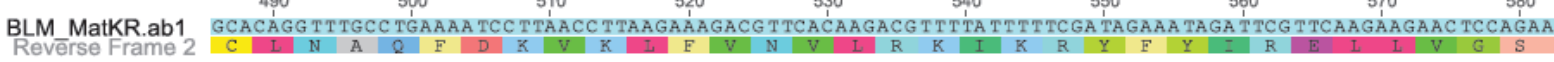

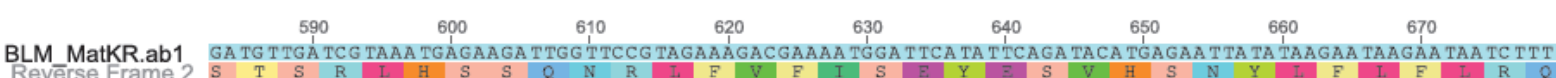
Revērse Frame 2 S

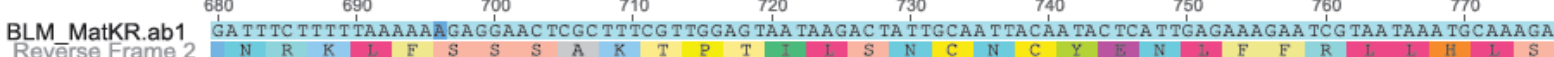
Revērse Frame 2 N $\quad$ N

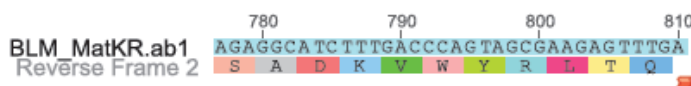

Gambar 3 - Urutan nukleotida dan asam amino hasil sekuensing primer reverse matK Rumput Macan. Baris atas menunjukkan urutan nukleotida dan baris bawah menunjukkan urutan asam amino.

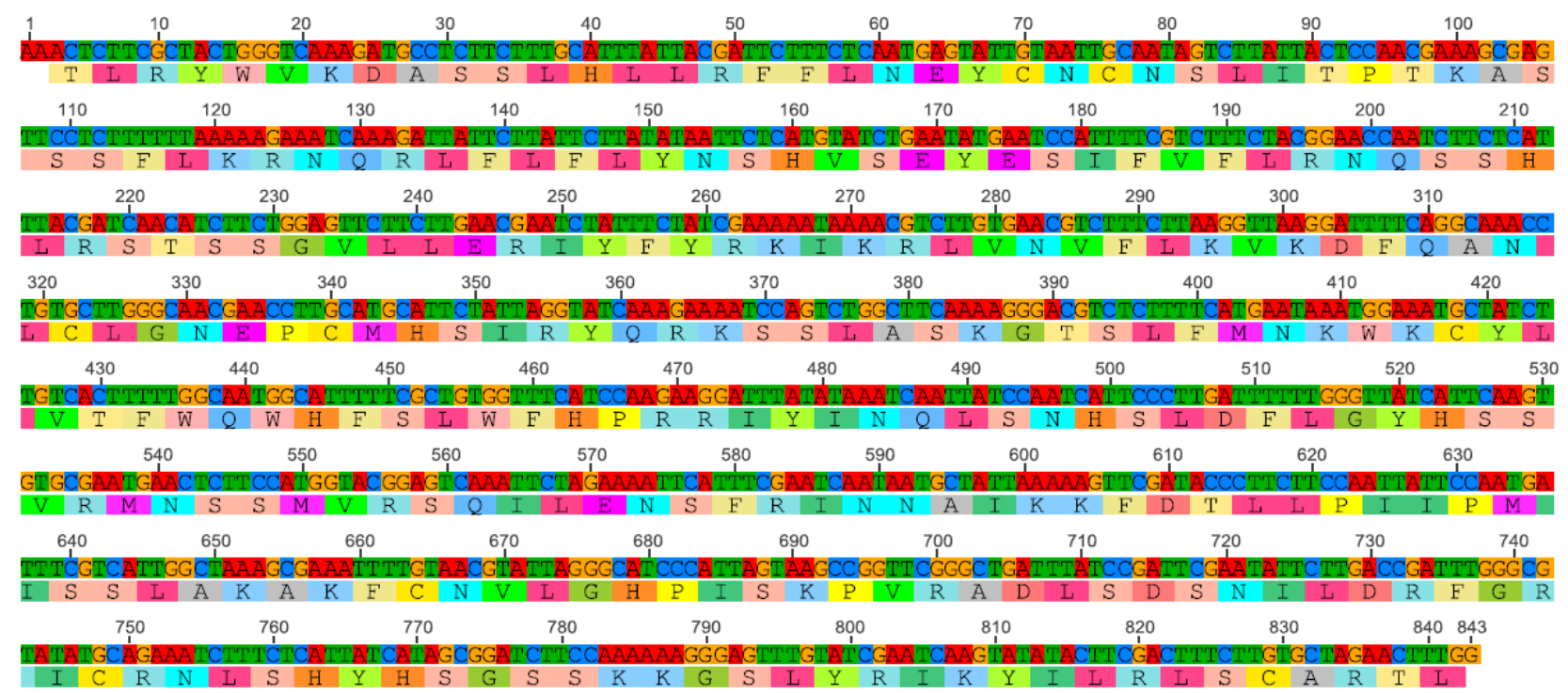

Gambar 4 - Barcode DNA Rumput Macan (L. camara L.). Baris atas menunjukkan urutan nukleotida dan baris bawah menunjukkan urutan asam amino.

\subsection{Sifat Fisika-Kimia Maturase K}

Berdasarkan komposisi asam-asam amino penyusunnya, maka dilakukan analisis sifat fisikakimia produk gen matK L. camara L. dengan menggunakan ProtParam yang tersedia dalam situs http://www.expasy.org/tools/protparam.html. hasil analisis sifat fisika-kimia matK L. camara L. menunjukkan nilai isoelektrik (pl) 10,00 yang menandakan bahwa L. camara L. bersifat basa. Nilai indeksinstabilitas (II) adalah 39,47 sehingga protein tersebut bersifat stabil. Untuk indeks Grand Average of Hydrophathicity (GRAVY), suatu nilai yang menunjukkan kemampuan suatu protein untuk 
berinteraksi dengan air, menunjukkan nilai yang rendah atau negatif yang menandakan bahwa protein L. camara L. dapat berinteraksi baik dengan air (hidrofobik) (Kyte dan Doolittle, 1982).

\section{Kesimpulan}

Gen matK Lantana camara berhasil diisolasi dan diamplifikasi dengan PCR. Hasil sekuensing menunjukkan bahwa sebanyak 746 pb berhasil diamplifikasi menggunakan primer forward, sedangkan primer reverse berhasil mengamplifikasi sebanyak $810 \mathrm{pb}$. Penggabungan hasil sekuensing primer forward dan reverse tersebut menghasilkan barcode DNA L. camara L sebanyak 843 pb. Untuk sifat-sifat fisika kimia menunjukkan bahwa matk Lantana camara L. bersifat basa, stabil, dan dapat berinteraksi baik dengan air.

\section{Daftar Pustaka}

CBOL (Consortium for the Barcode of Life) Plant Working Group. 2009. A DNA Barcodefor Land Plant. PNAS. 106: 12794-12797.

Dick, C. W. and W. J. Kress. 2009. Dissecting tropical plant diversity with forest plots and a molecular toolkit. Bioscience. 59: 745-755.
Hebert, P.D.N., N.A. Cywinska, S.L. Ball and J.R. de Waard. 2003. Biological identifications through DNA barcodes. Proc. Roy. Soc. B-Biol. Sci. 270: 313-321.

Hidayati, N. A., S. Listyawati dan A. D. Setyawan. 2008. Kandungan Kimia danUji Antiinflamasi Eksrtsk Etanol Lantana camara L. pada Tikus Putih (Rattus norvegicus L.) Jantan. Bioteknologi. 5: 10-17.

Hollingsworth, P. M., L. L. Forrest, J. L. Spouge, M. Hajibabaei, and R. Ratnasingham. 2009. A DNA Barcode for Land Plants. Proc. Natl. Acad. Sci. USA. 106: 12794-97.

Kyte, J. and R. F. Doolittle. 1982. A Simple Method for Displaying The Hydropathic Character of a Protein. J. Mol. Biol. 157: 105-132.

Lahaye, R., M. V. D. Bank, D. Bogarin, J. Warner, F. Pupulin, G. Gigot, O. Maurin, S. Duthoit, T. G. Barraclough and V. Savolainen. 2008. DNA barcoding the floras of biodiversity hotspots. Proc. Nat. Acad. Sci. 105: 2923-2928.

Xue, C.Y. and D.Z. Li. 2011. Use of DNA barcode sensu lato to identify traditional Tibetan medicinal plant Gentianopsis paludosa (Gentianaceae). J. Sys. Evol. 49: 267. 